\title{
МОЖЛИВОСТІ ШИРОКОГО ЗАСТОСУВАННЯ ТРИГЕРНОЇ ТАКТИКИ ВЕДЕННЯ ЖІНОК 3 ВИСОКИМ ПРОГНОСТИЧНИМ РИЗИКОМ ПІСЛЯПОЛОГОВОї КРОВОТЕЧІ
}

\author{
О. В. Голяновский, Н. О. Сінєнко \\ Національна медична академія післядипломної освіти імені П. Л. Шупика
}

\begin{abstract}
Резюме. Розглянуті можливості застосування нових принципів корекції патологічних змін в організмі шляхом періодичної спрямованої зміни системного ведення пацієнток на основі тригерних реакцій (каскаду тригерних реакцій). Показано, що клінічні «тригери«, або багатокомпонентні пороги для прийнятя рішеньдопомагають визначити статус пацієнток та переорієнтувати за необхідності характер медичного втручання.
\end{abstract}

\section{THE POSSIBILITY OF WIDE APPLICATION TRIGGERED TACTICS IN WOMEN WITH THREATENING POSTPARTUM HEMORRHAGE

\author{
O. V. Holianovskyi, N. O. Sinienko \\ Shupyk National Medical Academy of Postgraduate Education
}

\begin{abstract}
It was discussed the possibilities of application the new principles of correction of pathological changes in the body through periodic maintenance of directed modify the patients based trigger reactions (trigger cascade reactions). It is shown that the clinical «triggers» or multi thresholds for decisions help determine the status of patients and if necessary to refocus the nature of medical intervention.
\end{abstract}

Вступ. Нами неодноразово підкреслювалась висока актуальність проблеми прогнозування виникнення та лікування кровотеч в акушерстві та гінекології [3]. Так, кровотечі відносяться до числа найважливіших причин звернення жінок 3 гінекологічними захворюваннями в останні роки. До 65\% пацієнток репродуктивного віку звертаються до лікарів 3 приводу маткових кровотеч. Від 30 до 50 \% підлітків (залежно від регіону проживання) страждають порушеннями менструального циклу. Лікарі спостерігають «омолодження» міоми матки. Ще більш важливими є питання їх профілактики, які були і залишаються такими, що не мають остаточного вирішення. У будь-якому кластері проблем дискутуються також як логіка, так і послідовність медичних дій. Ще більш проблемними $\epsilon$ питання дотримання лікарем акушером-гінекологом чіткого алгоритму дій за різних варіантів розвитку післяпологової кровотечі. І у цих випадках тригерний підхід до терапії акушерської кровотечі надає можливість лікарю застосовувати найбільш оптимальний алгоритм дій за певної клінічної ситуації.

Мета дослідження. Проаналізувати можливості застосування нових принципів корекції патологіч- них змін в організмі породіллі шляхом періодичної спрямованої зміни системного ведення пацієнток на основі тригерних реакцій (каскаду тригерних реакцій).

Отримані результати. Розглядаючи профілактику кровотеч в родопомічних закладах, вибір тактики (активна, очікувальна), використання препаратів (наприклад, застосування окситоцину), можна зустріти самі протилежні думки. Хоча дослідниками 314 європейських держав в рамках інтернаціонального дослідження Євфрату вироблено Європейську угоду щодо попередження та ведення післяпологових кровотеч. Однак, незважаючи на рекомендації ВОО3, очікувальна тактика ще популярна в деяких країнах Північної Європи, ряді родопомічних установ США, Канади і часто є рутинною у разі ведення домашніх пологів в країнах, що розвиваються. Так, за даними А. Bjornerem i співавт. (2011), введення окситоцину для профілактики кровотечі використовували тільки у 47 \% пологових відділень Норвегії [1].

Підкреслимо, що очікувальна тактика має сенс, якщо при кожній можливій ситуації лікар має затверджений алгоритм дій. Зміна можливої активної тактики введення III періоду пологів отримала 
назву тригерних взаємодій, а точки зміни плану діагностики та лікування - тригерної точки.

Знайшли ці підходи в огляді керівництва Європейської спілки анестезіологів «Интенсивная терапия тяжелого периоперационного кровотечения», зокрема в спеціальному розділі «Триггеры трансфузии» [2].

Подібні підходи почали впроваджувати в медицині досить активно, в тому числі й в акушерстві та гінекології [4]. В Україні подібна стратегія ще не набула розповсюдження.

Нами досліджена можливість використання тригерних схем в акушерстві за післяпологових кровотеч для своєчасної діагностики та обгрунтованого їх лікування. Зокрема, були побудовані онтологічні моделі медичних знань при кровотечах, що відповідає сучасним уявленням у цьому напрямку [3]. Досліджені також каскадні процеси згортання крові у разі кровотечі з урахуванням контактів 3 поверхнею, тканинним фактором, рівня тромбоцитів, стану калікреїн-кінінової системи, інгібіції зовнішнього шляху згортання і т.д.

Найважливішою частиною дослідження стали різні шляхи введення породіль за невідкладних станів (наприклад, за геморагічного шоку). Ви- ділено низку ключових ознак (об'єм кровотечі, збільшення материнської смертності (наприклад, $<95 \%$ ), наявність олігурії. Через ці проблеми експерти рекомендують, щоб лікарі використовували клінічні «тригери», або багатокомпонентні пороги для визначення об'єму материнської крововтрати i, зважаючи на це, переорієнтували характер медичного втручання.

Запропоновані «тригери» включають абсолютний поріг втрати крові (наприклад, 500 мл після вагінальних пологів або 1000,0 мл за кесарева розтину), життєві ознаки - наприклад, збільшення частоти серцевих скорочень більш ніж на $15 \%$ або абсолютного значення - більш 110 уд/хв., артеріального тиску $(<85 / 45)$, а також насичення киснем крові - наприклад, $<95 \%$ ).

Висновки. 1. Запропоновано широке використання клінічних тригерів для обгрунтування диференційованого підходу до стратегії й тактики лікування жінок $з$ акушерськими кровотечами.

2. Рекомендовано внести доповнення в стандарти надання медичної допомоги та алгоритми дій в акушерсько-гінекологічних стаціонарах на основі використання клінічних тригерів.

\section{Література}

1. Bj0rnerem A. Postpartum hemorrhage - prophylaxis and treatment in Norway / A. Bj0rnerem, G. Acharya, P. 0ian // T. Norske Laegeforen. - 2002. - Vol. 122, № 26. - P. 2536-2537.

2. Обзор руководства Европейского общества анестезиологов «Интенсивная терапия тяжелого периоперационного кровотечения» (2013) [Текст] / И. А. Йовенко; Днепропетровская областная клиническая больница им. И. И. Мечникова // Острые и неотложные состояния в практике врача. - 2014. - № 5. - С. 47-55.

3. Голяновський О.В.Логіка міждисциплінарного підходу до своєчасної діагностики та лікування кровотеч

\footnotetext{
в акушерстві та гінекології: побудова задачної онтології / О. В. Голяновський, Н. В. Сінєнко, О. М. Вернер // Медична інформатика та інженерія. - 2014. - № 4. C. 57-60.

4. Florida Obstetric Hemorrhage Initiative (OHI) Toolkit: A Quality Improvement Initiative for Obstetric Hemorrhage Management [Electronic resourse]. Version 12/2014. - Mode of access: http://health. usf.edu/NR/rdonlyres/880 8ABE3-D150-43 53-BA81DFAF175 1A449/50870/FL0HIToolkitv102015.pdf.
} 